Abstract-We used estimates of shrimp density, growth, mortality, and secondary production during an 84-d sampling period to compare the value of nursery habitat for juvenile white shrimp (Litopenaeus setiferus) among 3 salinity zones (intermediate, brackish, and saline zones) within Sabine Lake, an estuary of the northern Gulf of Mexico. Density, growth, mortality, and secondary production were generally higher in the saline or brackish zones and lowest in the intermediate zone. The saline and brackish zones appeared to provide the most important nursery habitat on a per-area basis, but the intermediate zone also may contribute substantially to total shrimp production; although production in the intermediate zone was modest, this zone encompasses a relatively large portion $(26 \%)$ of coastal wetlands in Louisiana. The relative value of nursery areas can be dynamic; variation occurs both spatially (e.g., within an estuary and among estuaries) and temporally (e.g., from year to year). We documented within-estuary differences (i.e., differences among salinity zones within the estuary) in the value of nursery habitat for white shrimp in Sabine Lake and expect this value, especially in the intermediate zone, to vary interannually. The dynamic nature of habitats should be considered when assessing the value of estuarine nursery areas.

Manuscript submitted 16 October 2015. Manuscript accepted 26 September 2016. Fish. Bull. 115(1):74-88 (2017).

Online publication date: 22 November 2016. doi: 10.7755/FB.115.1.7

The views and opinions expressed or implied in this article are those of the author (or authors) and do not necessarily reflect the position of the National Marine Fisheries Service, NOAA.

\title{
Population dynamics and secondary production of juvenile white shrimp (Litopenaeus setiferus) along an estuarine salinity gradient
}

\author{
Marvin M. Mace III' \\ Lawrence P. Rozas ${ }^{2}$ \\ Email address for contact author: marvin.mace.iii@gmail.com \\ 1 Department of Biology \\ University of Louisiana at Lafayette \\ P.O. Box 42451 \\ Lafayette, Louisiana 70504 \\ 2 Estuarine Habitats and Coastal Fisheries Center \\ Southeast Fisheries Science Center \\ National Marine Fisheries Service, NOAA \\ 646 Cajundome Boulevard \\ Lafayette, Louisiana 70506
}

Penaeid shrimps support several valuable commercial fisheries in the United States. Three species, brown shrimp (Farfantepenaeus aztecus), pink shrimp ( $F$. duorarum), and white shrimp (Litopenaeus setiferus), within the family make up most of the landings in terms of weight and economic value $\left(\mathrm{NMFS}^{1}\right)$. Most white shrimp are landed in the western Gulf of Mexico, specifically in Louisiana and Texas $\left(\mathrm{NMFS}^{1}\right)$.

The white shrimp is an estuarinedependent species that occurs inshore during the early phase of its life history. Spawning takes place offshore from late spring to early fall, postlarvae migrate into estuarine habitat, and juvenile shrimp use this nursery habitat for $~ 7-16$ weeks before returning offshore to complete their life cycle (Muncy, 1984; Baker et al., 2014). The importance of estuarine nursery areas in supporting populations of juvenile penaeid shrimps, such as white shrimp, is

${ }^{1}$ NMFS (National Marine Fisheries Service). 2015. Commercial fishery landings. [Available at website, accessed October 2015.] widely accepted, but the suitability of this habitat for penaeid shrimps often varies among and within estuaries (Vance et al., 1998; Rozas and Minello, 2010, 2011; Palmer and Montagna, 2015).

Vegetated aquatic habitats (e.g., tidal marshes, mangroves, and seagrasses) within estuaries are thought to provide essential habitat for many species of fish and crustaceans (Kneib, 1997; Kathiresan and Bingham, 2001; Heck et al., 2003; Minello et al., 2003). Tidal marshes, in particular, are believed to be important, especially for the young of commercially important species, including white shrimp (Boesch and Turner, 1984; Kneib, 1997). In coastal Louisiana, tidal marshes are disappearing at a rapid rate because of a variety of natural and anthropogenic causes (Turner, 1990), and identifying areas that are important nurseries for fishery species should be a priority for conserving coastal habitats.

The density (abundance) and vital rates (growth and mortality) of juvenile white shrimp in estuaries may be useful indicators of habitat value and their contribution to adult 
stocks (Diop et al., 2007; NMFS, 2010; Baker et al., 2014). Abundance of early juvenile white shrimp is, for example, a good predictor of late juvenile shrimp abundance, which is itself a good predictor of the number of shrimp landed by the fishery (Diop et al., 2007). The white shrimp is harvested as an annual fishery crop (Nance et al., 2010), and survival during the juvenile life stage may have a larger effect on the adult population than adult mortality or fecundity (Baker et al., 2014). Mortality may decrease as the size of juvenile white shrimp increases (Baker and Minello, 2010); therefore, growth also could be an important factor that influences the recruitment success of white shrimp to the fishery.

Salinity is a major environmental factor thought to influence the use of estuarine nursery areas by white shrimp and other nekton at the landscape scale (Weinstein et al., 1980; Rakocinski et al., 1992; Wagner and Austin, 1999; Rozas and Minello, 2010). For example, juvenile white shrimp are reported to be most abundant in mesohaline and polyhaline environments of estuaries (Gunter et al., 1964; Howe et al., 1999; Minello, 1999; Rozas and Minello, 2010), although they range much more widely in salinities $<1$ and $\geq 35$ (Gunter et al., 1964). These observations are based mainly on comparisons of shrimp density, abundance, or catch per unit of effort from samples collected within estuarine habitats of differing salinity. Density alone, however, may be an insufficient indicator of habitat quality (Van Horne, 1983); additional measures, such as growth, mortality, or secondary production, can provide a more comprehensive picture of habitat quality (Van Horne, 1983; Beck et al., 2001; NMFS, 2010; Dolbeth et al., 2012).

We are unaware of any other study in which this full suite of metrics (density, growth, mortality, and secondary production) has been incorporated to compare nursery areas of white shrimp along an estuarine salinity gradient. Few studies have examined the effect of salinity on growth and mortality of young white shrimp (Zein-Eldin and Griffith, 1969; Rozas and Minello, 2011), and available estimates indicate that secondary production of white shrimp is higher in estuaries of the northern Gulf of Mexico than in those of the U.S. Atlantic coast (Zimmerman et al., 2000; Kneib, 2003; Minello et al., 2008). Habitat-specific vital rates (growth and mortality) and estimates of secondary production are needed to fully assess and compare nursery areas among different salinity regimes. This information can be used 1) to identify important nursery areas and essential habitats (Beck et al., 2001), 2) to develop detailed population models and improve stock assessment models for white shrimp (Baker et al., 2014), and 3) to calibrate ecosystem models used to predict effects of human activities on this and other estuarine species (Rose et al., 2014).

The purpose of our study was to measure and compare the value of nursery habitat for white shrimp in 3 salinity zones in the Sabine Lake estuary along an estuarine salinity gradient. We collected quantitative density data from each salinity zone in summer and fall, when white shrimp were most abundant in the estuary. Length-frequency data from these samples were used to examine size distributions and to estimate growth and mortality rates among the 3 salinity zones. We used these data and the size-frequency method (Garman and Waters, 1983) to estimate and compare secondary production of white shrimp among salinity zones.

\section{Materials and methods}

\section{Study site}

Our study was conducted in the Sabine Lake estuary (hereafter referred to as Sabine Lake) which is located in southwest Louisiana within the area of the coast known as the Chenier Plain (Fig. 1). Sabine Lake encompasses an area of 375,979 ha; approximately half (49\%) of that area is composed of marshes (Gosselink et al $^{2}$ ). Marshes in coastal Louisiana are classified into salinity zones based on dominant vegetation (Chabreck, 1970; Visser et al., 1998, 2000). We selected 3 salinity zones (intermediate, brackish, and saline) using this vegetation classification rather than water salinity measured at sampling sites because conditions in estuaries are in constant flux. Vegetation (e.g., marsh type) represents average environmental conditions (e.g. salinity regime) integrated over time better than a single salinity measurement. The salinity ranges for these vegetation-based zones tend to be $0.5-5.0$ for intermediate, 5.0-18.0 for brackish, and 18.0-36.0 for saline. Salinity in any zone, however, occasionally may extend outside the typical range. These 3 salinity zones are comparable to the oligohaline, mesohaline, and polyhaline zones, respectively, of the Venice system (Anonymous, 1958; Visser et al., 1998).

\section{Sampling procedure}

White shrimp were sampled during 6 sampling trips in 2011 (Table 1) that commenced on July 12 (trip 1) and 26 (trip 2), August 9 (trip 3), September 7 (trip 4) and 20 (trip 5), and October 4 (trip 6). A 1- $\mathrm{m}^{2}$ drop sampler (Zimmerman et al., 1984) was used to collect 45-60 samples during each of these sampling trips, which each required 3 days to complete (with one salinity zone completed each day). Details of our sampling design are given in Mace and Rozas (2015). Briefly, we selected an area of $1 \mathrm{~km} \times 1 \mathrm{~km}$ within each salinity zone, divided it into 16 squares of equal size $(0.25 \mathrm{~km} \times 0.25$ $\mathrm{km}$ ), and, before each sampling trip, we randomly selected 5 of these squares for sampling. To obtain a rep-

\footnotetext{
${ }^{2}$ Gosselink, J. G., C. L. Cordes, and J. W. Parsons. 1979. An ecological characterization study of the Chenier Plain coastal ecosystem of Louisiana and Texas. 3 vols., FWS/OBS-78/9, 78/10, and 78/11. Natl. Coast. Ecosyst. Team, Off. Biol. Serv., U.S. Fish Wildl. Serv., Slidell, LA.
} 


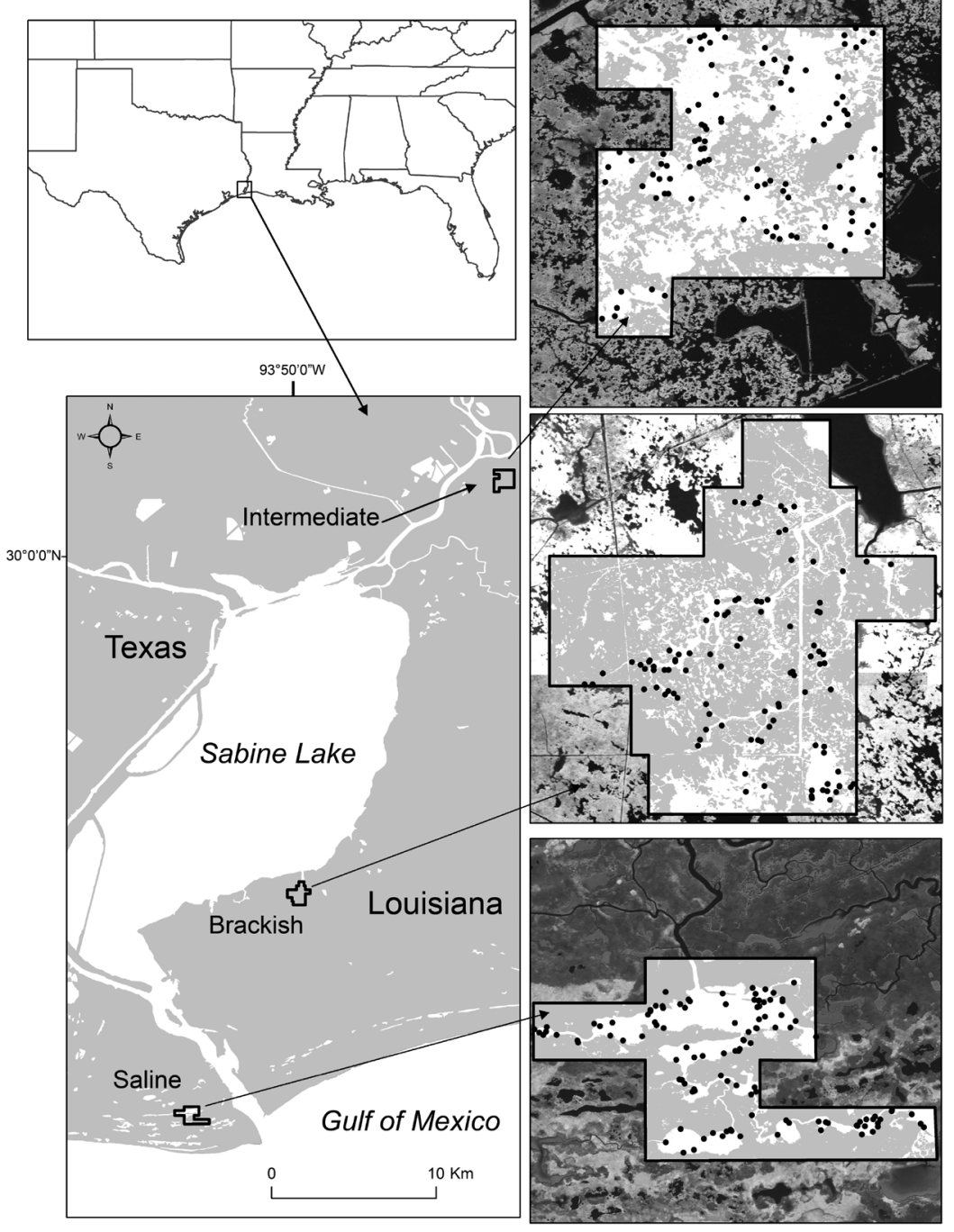

Figure 1

Map of the study area in Sabine Lake (at the border of Texas and Louisiana). Samples of juvenile white shrimp (Litopenaeus setiferus) were collected in 2011 to estimate density, natural mortality, growth, and secondary production at 3 locations along the estuarine salinity gradient (zones=intermediate, brackish, and saline) that were each 100 ha in size. Black dots represent locations where individual drop samples were collected.

resentative sample of the shrimp population from each selected square, a drop sample was taken from each of 4 habitat types where shrimp are known to occur: 1) marsh vegetation $\leq 1 \mathrm{~m}$ from the interface of marsh and open water (marsh edge), 2) shallow water $\leq 1 \mathrm{~m}$ from the marsh edge (SW1), 3) shallow water 1-5 $\mathrm{m}$ from the marsh edge (SW1-5), and 4) shallow water $>5 \mathrm{~m}$ from the marsh edge $(\mathrm{SW}>5)$.

Locations of SW $>5$ sampling sites were determined by randomly selecting distances between $6 \mathrm{~m}$ from the nearest shore and the middle of the water body. Only 3 of the 4 habitat types were sampled on the first 3 sample dates in most of the salinity zones when low water levels precluded sampling at the marsh edge
(Table 1). Before collecting each drop sample, salinity, temperature, depth, and turbidity were measured according to the protocol described in Rozas et al. (2012). Each nekton sample was placed on ice, preserved in $10 \%$ formalin at the end of the day, and transported to the laboratory for processing. In the laboratory, all organisms were separated from detritus, and juvenile penaeid shrimps were identified to species by using the characters from Pérez Farfante ${ }^{3}$, Ditty (2011), and references therein. Carapace length was measured for all juvenile white shrimp as described in Mace and Rozas (2015).

The duration of flooding for each habitat was estimated by using water levels measured in the field and equations fitted for each salinity zone (Minello et al., 2012). We collected data on water levels at 20 randomly located transects within each salinity zone. Along each transect, water levels were measured at the marsh edge and at 0.5 , $1,2,3,4$, and $5 \mathrm{~m}$ on each side of the marsh edge. To derive equations for estimating long-term water levels in each salinity zone, we regressed water-level data from temporary tide gauges placed in each salinity zone against data from nearby tide gauges of the NOAA Center for Operational Oceanographic Products and Services (CO-OPS: website) and the U.S. Geological Survey's Coastwide Reference Monitoring System (CRMS; website): NOAA station 8770570 for the saline zone, NOAA station 8770475 for the brackish zone, and CRMS site 0662 for the intermediate zone. We estimated the flooding durations (percentage of time water depth was $\geq 5 \mathrm{~cm}$ ) at habitats in each salinity zone from July through October 2011 by relating the water depth measured at each transect sampling site to concurrent tide data calculated from these fitted equations.

Size

We examined size, measured as total length in millimeters, of white shrimp collected in our samples by comparing box plots of size for each salinity zone and sample date. Descriptive statistics, such as minimum,

\footnotetext{
${ }^{3}$ Pérez Farfante, I. 1970. Diagnostic characters of juveniles of the shrimps Penaeus aztecus aztecus, $P$. duorarum duorarum, and P. brasiliensis (Crustacea, Decapoda, Penaeidae). U.S. Fish Wildl. Serv., Specl. Sci. Rep. Fish. 599, 26 p.
} 


\begin{tabular}{|c|c|c|c|c|c|c|c|}
\hline \multicolumn{8}{|c|}{$\begin{array}{l}\text { Distribution of samples used to estimate density, natural mortality, growth, and secondary production } \\
\text { of juvenile white shrimp (Litopenaeus setiferus) in Sabine Lake. Samples were collected on } 6 \text { sampling } \\
\text { trips in } 2011 \text { in } 3 \text { salinity zones (intermediate, brackish, and saline) and } 4 \text { habitat types }(1-\text { marsh } \\
\text { edge, or marsh vegetation } \leq 1 \mathrm{~m} \text { from the interface of marsh and open water [ME]; } 2 \text {-shallow water } \leq 1 \\
\mathrm{~m} \text { from the marsh edge [SW1]; } 3-\text { shallow water } 1-5 \mathrm{~m} \text { from the marsh edge [SW1-5]; and } 4-\text { shallow } \\
\text { water }>5 \mathrm{~m} \text { from the marsh edge [SW }>5] \text { ). }\end{array}$} \\
\hline \multirow[b]{2}{*}{ Zone } & \multirow[b]{2}{*}{ Trip } & \multirow[b]{2}{*}{ Date } & \multicolumn{4}{|c|}{ Habitat } & \multirow[b]{2}{*}{ Total } \\
\hline & & & $\mathrm{ME}$ & SW1 & SW1-5 & $\mathrm{SW}>5$ & \\
\hline \multirow[t]{6}{*}{ Intermediate } & 1 & 07/12/11 & 0 & 5 & 5 & 5 & 15 \\
\hline & 2 & $07 / 26 / 11$ & 0 & 5 & 5 & 5 & 15 \\
\hline & 3 & $08 / 9 / 11$ & 0 & 10 & 5 & 5 & 20 \\
\hline & 4 & 09/9/11 & 5 & 5 & 5 & 5 & 20 \\
\hline & 5 & 09/20/11 & 5 & 5 & 5 & 5 & 20 \\
\hline & 6 & $10 / 4 / 11$ & 5 & 5 & 5 & 5 & 20 \\
\hline \multirow[t]{6}{*}{ Brackish } & 1 & 07/13/11 & 0 & 5 & 5 & 5 & 15 \\
\hline & 2 & 07/27/11 & 0 & 5 & 5 & 5 & 15 \\
\hline & 3 & 08/10/11 & 0 & 10 & 5 & 5 & 20 \\
\hline & 4 & 09/7/11 & 5 & 5 & 5 & 5 & 20 \\
\hline & 5 & 09/21/11 & 5 & 5 & 5 & 5 & 20 \\
\hline & 6 & $10 / 5 / 11$ & 5 & 5 & 5 & 5 & 20 \\
\hline \multirow[t]{6}{*}{ Saline } & 1 & $07 / 14 / 11$ & 0 & 5 & 5 & 5 & 15 \\
\hline & 2 & 07/28/11 & 5 & 5 & 5 & 5 & 20 \\
\hline & 3 & $08 / 11 / 11$ & 0 & 10 & 5 & 5 & 20 \\
\hline & 4 & 09/8/11 & 5 & 5 & 5 & 5 & 20 \\
\hline & 5 & $09 / 22 / 11$ & 5 & 5 & 5 & 5 & 20 \\
\hline & 6 & $10 / 6 / 11$ & 5 & 5 & 5 & 5 & 20 \\
\hline
\end{tabular}

maximum, and mean size, were also computed for salinity zones and sample dates.

\section{Density}

We restricted our analysis of shrimp density to the last 3 sampling trips when sample sizes were equal both among habitats types and salinity zones (Table 1). Before analysis, these density data were $\ln (x+1)$ transformed to remove the relationship between the mean and variance present in untransformed data (Milliken and Johnson, 1992). We used an analysis of variance (ANOVA) with 3 factors: 1) salinity zone (intermediate, brackish, saline), 2) habitat type (marsh edge, SW1, SW1-5, SW>5), and 3) sampling trip (4 to 6 ). The ANOVA model included a 3 -way interaction, all 2 -way interactions, and all main effects. After a significant main effect of habitat type, 3 a priori contrasts were made: 1) marsh edge versus SW1, 2) SW1 versus SW1-5+SW $>5$, and 3) marsh edge versus SW1+SW1$5+\mathrm{SW}>5$. The first and third contrasts allowed us to compare marsh edge with adjacent shallow water and all shallow-water sites combined, respectively. We compared shallow-water sites near $(<1 \mathrm{~m})$ and those sites farther away from the marsh edge with the second contrast. Results were considered significant at $P<0.05$. We also estimated omega squared $\left(\omega^{2}\right)$ for each factor in the ANOVA, using the formulas for measured factors given in Olejnik and Algina (2003). Omega squared is an estimate of effect size that can be interpreted as the proportion of variance explained by a given factor in an ANOVA. All density data presented in the text, tables, and figures are untransformed means.

\section{Mortality}

We converted length-frequency distributions to agefrequency distributions to estimate mortality. Before converting to age-frequency distributions, length-frequency distributions were weighted to account for differences in the relative amount of habitat types within each salinity zone (Suppl. Table 1). Weighting was accomplished by first constructing length-frequency distributions for each habitat type within a salinity zone and then multiplying the number of individuals in each size class by the total area of a given habitat type in that zone, resulting in 4 different length-frequency distributions for each zone on each sample date. Lengthfrequency data from samples collected in marsh edge habitat were applied to the entire marsh within $5 \mathrm{~m}$ of the shoreline, although densities of juvenile white shrimp may decline as distance from the shoreline increases from 1 to $5 \mathrm{~m}$ into marsh vegetation (Minello et al., 2008). Because we were interested in the entire 
shrimp population in each salinity zone on each sample date, we combined length-frequency distributions from all 4 habitat types in each zone from each sample date. Finally, we converted the combined length-frequency distribution in each salinity zone on each sample date into a relative frequency distribution and apportioned the total number of shrimp collected in each zone on each sample date to fit this distribution. These weighted length-frequency distributions were used in subsequent analyses of mortality and growth.

Daily instantaneous mortality rates $(Z)$ were estimated in each salinity zone by using a horizontal catch-curve analysis (Vetter, 1988). We assumed $Z$ was equal to the daily instantaneous natural mortality rate $(M)$ because there was no fishery for juvenile white shrimp in our study area, and we removed only a very small fraction of the total population during our sampling. We combined and converted length-frequency data from multiple sampling trips within each salinity zone to age-frequency data by assuming a growth rate of $1 \mathrm{~mm} \mathrm{TL} / \mathrm{d}$, a reasonable assumption for juvenile penaeid shrimps in general (Dall et al., 1990) and white shrimp specifically (Rozas and Minello, 2011).

Using the age-frequency data, we calculated mortality with the following 2 methods: 1) a linear regression of the $\ln ($ density+0.1) against age, where the slope is an estimate of mortality (Ricker, 1975) and 2) the Chapman-Robson estimator (Chapman and Robson, 1960) with the standard error corrected for overdispersion (Smith et al., 2012). We started the catch curve with the regression method at the age of highest abundance and included all ages up to but not including the first age at which time there were $\leq 1$ individual (Smith et al., 2012). For the Chapman-Robson estimator, we included all ages greater than the age of peak abundance. We compared mortality rates between catchcurve methods and among salinity zones by first taking the difference between 2 estimates and then constructing a 95\% confidence interval (CI) for the difference. We considered results significantly different when the 95\% CI of the difference between 2 estimates did not include zero (Schenker and Gentleman, 2001).

\section{Growth}

We calculated growth rates by following individual cohorts and using the mean size of a cohort on 2 consecutive sample dates to estimate a mean growth rate between sample dates. Individual cohorts of shrimp were identified from each of the length-frequency distributions on different sample dates in each salinity zone by using the mixdist package, vers. 0.5-4 (Macdonald and $\mathrm{Du}, 2012$ ) in $\mathrm{R}$, vers. 3.1.0 ( $\mathrm{R}$ Core Team, 2014), and the mean growth rate for a cohort between sample dates was calculated as

$$
G_{\text {absolute }}=\frac{\mu_{\mathrm{t}+1}-\mu_{\mathrm{t}}}{t_{\mathrm{t}+1}-t_{1}},
$$

where $\mu_{\mathrm{t}}=$ the mean carapace length at time $t$; and $\mu_{\mathrm{t}+1}=$ the mean carapace length at time $t+1$.
Before calculating growth, carapace length was converted to total length by using the formula $\mathrm{TL}=\mathrm{CL}$ $\times 4.944$ (Baker and Minello, 2010). This conversion makes it easier to compare our growth rates with published values. Mean growth rates among salinity zones were compared as described above for mortality rates.

For each sample date in each salinity zone, we attempted to model cohorts by using normal, lognormal, or gamma distributions based on previous observations of length-frequency distributions of penaeid shrimp as they immigrated into estuaries (Baxter and Renfro, 1967). We used Akaike's information criterion adjusted for small sample size (AICc), $\triangle \mathrm{AICc}$ values (the difference in AICc values between a given model and the model with the lowest $\mathrm{AICc}$ value), and $w_{\mathrm{i}}$ values (AIC weights, which can be interpreted as an estimate of the probability that a given model is the best among all models considered, given the data) to compare and select the best model or models that described the shape and the mean size and standard deviation of the mean of shrimp cohorts (Burnham and Anderson, 2002).

\section{Secondary production}

Secondary production that occurred in each salinity zone over the 84-d sampling period was estimated in kilograms per hectare with the size-frequency method (Garman and Waters, 1983) because we were not able to track cohorts over all sample dates. The sizefrequency method uses the mean number and weight of individuals in each size class over time to estimate the biomass lost as individuals move through the sizefrequency distribution. We used shrimp up to $60 \mathrm{~mm}$ TL to estimate secondary production because shrimp larger than this size begin to emigrate from estuaries into the Gulf of Mexico (Pullen and Trent, 1969). We used the length-to-weight conversion given in Minello et al. (2008) to estimate mean shrimp weights and assumed this relationship was similar for all 3 salinity zones. We also estimated total biomass, measured in kilograms per hectare, within each salinity zone for the 84-d sampling period as the sum of the mean biomass of all size classes over all sample dates.

One of the most influential parameters affecting production estimates with the use of the size-frequency method is the cohort production interval (CPI) (Benke, 1979; Garman and Waters, 1983). The size-frequency method was originally developed to estimate production for insects whose larvae develop in aquatic habitats and produce only one generation per year. This original method was modified by including the CPI into the calculation to account for species that have multiple generations per year. Benke (1979) originally defined the CPI in terms of the amount of time taken to complete larval development (i.e., the aquatic stages when growth and production occur). Garman and Waters (1983) defined the CPI for fish as the average maximum age obtained by individuals in the population.

In our study, the age of a shrimp depended on its length because we estimated age from length; there- 


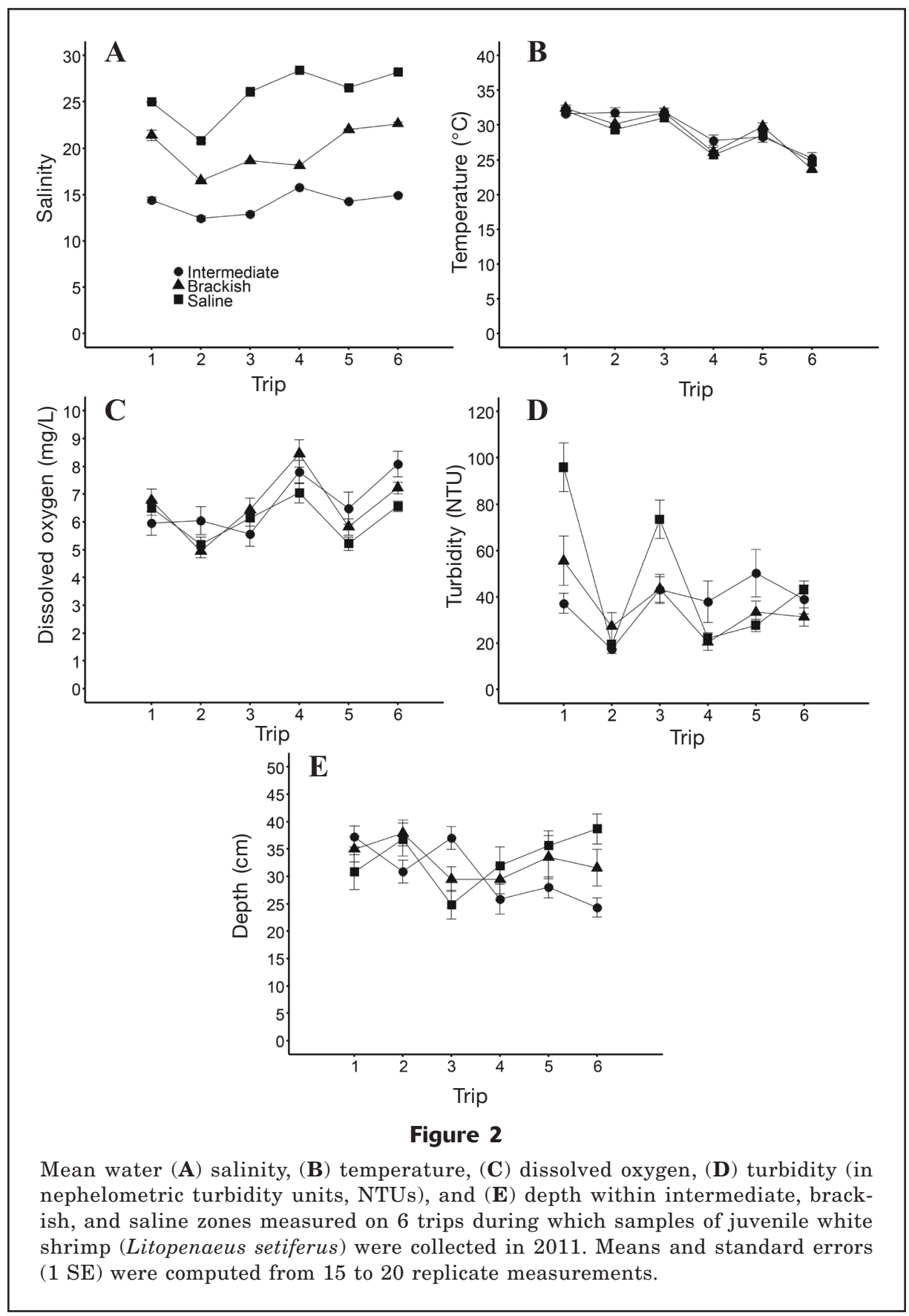

fore, growth rates could have affected our age estimates and the resultant CPI. We used a conservative approach for initial estimates of secondary production by assuming that shrimp in each salinity zone had the same CPI of $53 \mathrm{~d}$ (i.e., the maximum age of a shrimp since recruitment to the population as a $7 \mathrm{~mm}$ TL postlarva until migration out of the population at $60 \mathrm{~mm}$ $\mathrm{TL}$, assuming a growth rate of $1 \mathrm{~mm} \mathrm{TL/d).} \mathrm{We} \mathrm{also}$ calculated secondary production using CPIs for shrimp in each salinity zone based on the growth rates we estimated as described above. For example, if the mean growth rate that we estimated for a salinity zone was
$2 \mathrm{~mm} \mathrm{TL} / \mathrm{d}$, a 60-mm-TL shrimp that arrived in the population at $7 \mathrm{~mm}$ TL would have aged $27 \mathrm{~d}$ since it arrived in the population. Therefore, the CPI based on this $2 \mathrm{~mm}$ TL/d growth rate would be 27 .

\section{Results}

\section{Environmental variables}

Environmental variables, other than salinity, differed little among salinity zones (Fig. 2). Southwest Loui- 


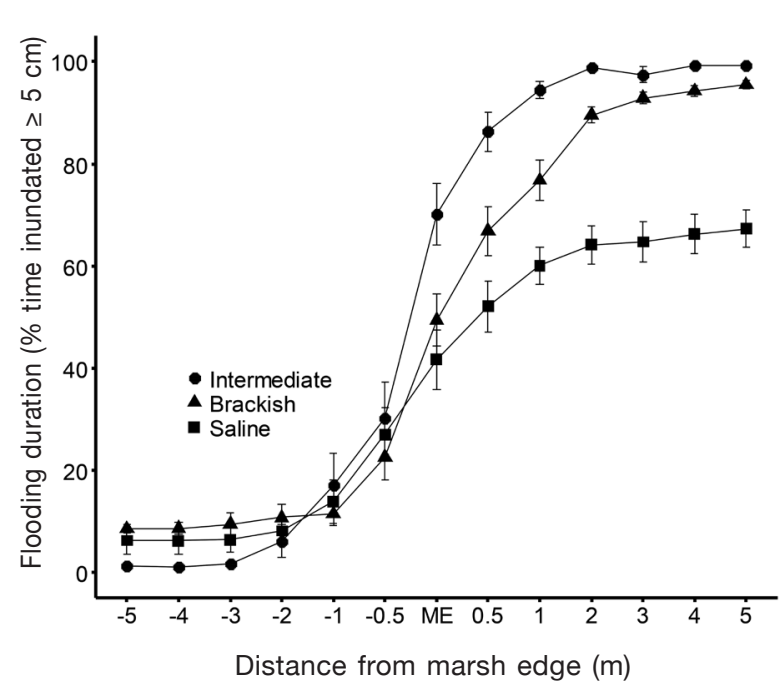

Figure 3

Comparison of mean flooding duration (number of hours water depth was $\geq 5 \mathrm{~cm} /$ total number of hours $\times 100$ ) for marsh edge and shallow-water sites among 3 different salinity zones (intermediate, brackish, and saline) in Sabine Lake from July 2011 through October 2011. Negative values indicate distances (from the marsh edge) within marsh vegetation, and positive values are distances from the marsh edge over shallow water. Means and standard errors (1 SE) were calculated from 20 replicate measurements.

siana experienced drought conditions starting in late 2010 until the end of 2011 (NOAA National Centers for Environmental Information, Climate Data Online, website, accessed October 2015). As a result, mean salinities during our study in Sabine Lake were slightly outside the range typical for the brackish zone and well above the normal range for the intermediate zone (Fig. 2). Mean water temperature varied little among salinity zones during each sampling trip and was slightly lower during the last 3 trips than during the first 3 trips. Mean dissolved oxygen was less variable during the first 3 sampling trips than during the last 3 trips, but no clear trend was detected in dissolved oxygen among salinity zones. We observed no consistent trend in either mean water depth or turbidity among salinity zones.

Flooding duration varied among salinity zones and distances from the marsh edge (Fig. 3). The marsh edge habitat was flooded for the highest percentage of the time in the intermediate zone $(70 \%)$, followed by the brackish $(50 \%)$ and saline $(42 \%)$ zones. The mean duration of flooding of the vegetated marsh surface $>0.5 \mathrm{~m}$ from the marsh edge (i.e., the negative numbers on the $x$-axis in Fig. 3 ) was relatively short ( $<20 \%$ of the time) in all 3 salinity zones. In the saline zone, shallow-water sites within $5 \mathrm{~m}$ of the marsh edge were flooded for relatively short durations as well (Fig. 3).
Size

White shrimp ranged in size from 4 to $126 \mathrm{~mm} \mathrm{TL}$, on the basis of data from all 6 sampling trips to the 3 salinity zones. Most shrimp (98\%), however, were juveniles $<60 \mathrm{~mm} \mathrm{TL}$, and, in general, size distributions and mean sizes were similar among salinity zones and sampling dates (Fig. 4). Mean size on most sampling dates ranged from 12 to $35 \mathrm{~mm}$ TL, except in the intermediate zone on trip 5 when mean size was $41 \mathrm{~mm}$ TL.

\section{Density}

Mean densities varied among habitat types, salinity zones, and sample dates (Table 2). The overall ANOVA model was significant $(P<0.001)$ and accounted for $60 \%$ of the variation in the shrimp density data. All 3 main effects were significant, as were the interactions between habitat type and salinity zone and between salinity zone and sampling trip; the 3 -way interaction was not significant (Table 3 ).

Habitat type was the most important factor in the model, and it accounted for an order of magnitude more variation $(45 \%)$ in the density data than that of any other factor $(\leq 6 \%$, Table 3$)$. The interaction of habitat type with salinity zone was weak, accounting for only $4 \%$ of the variation in the density data. Results from a priori contrasts indicated that shrimp densities were higher in the marsh edge habitat than in adjacent shallow water $(P=0.0379)$, higher in shallow water near the marsh edge than in other shallow-water sites $(P<0.0001)$, and higher at the marsh edge sites than at all shallow-water sites combined $(P<0.0001)$.

Mean shrimp density in each habitat type was generally highest in the saline zone. For example, mean shrimp densities at the marsh edge sites were estimated as 41.5 individuals $/ \mathrm{m}^{2}$ (standard error [SE] 10.2), 56.7 individuals $/ \mathrm{m}^{2}$ (SE 11.2), and 85.1 individuals/ $\mathrm{m}^{2}$ (SE 22.6) for the intermediate, brackish, and saline zones, respectively (Table 2). The SW1 habitat type was an exception; mean density at this type of habitat (based on the last 3 sampling trips) was highest in the brackish zone and lowest in the intermediate zone (Fig. $5)$. Although the main effect of salinity zone was significant, this effect varied by sample date; mean density was usually highest in the saline zone, except for on trip 5 when mean density was higher in the brackish zone than in the saline zone (Fig. 6).

\section{Mortality}

We estimated mortality by combining shrimp lengthfrequency data from the last 3 sampling trips in each salinity zone and conducting 2 catch-curve analyses per zone. Within a salinity zone, no difference in mortality rates could be detected between the results of the 2 catch-curve analyses (Table 4). Among salinity zones, no statistically significant difference in mortality rates was detected between the saline (0.09 [SE 


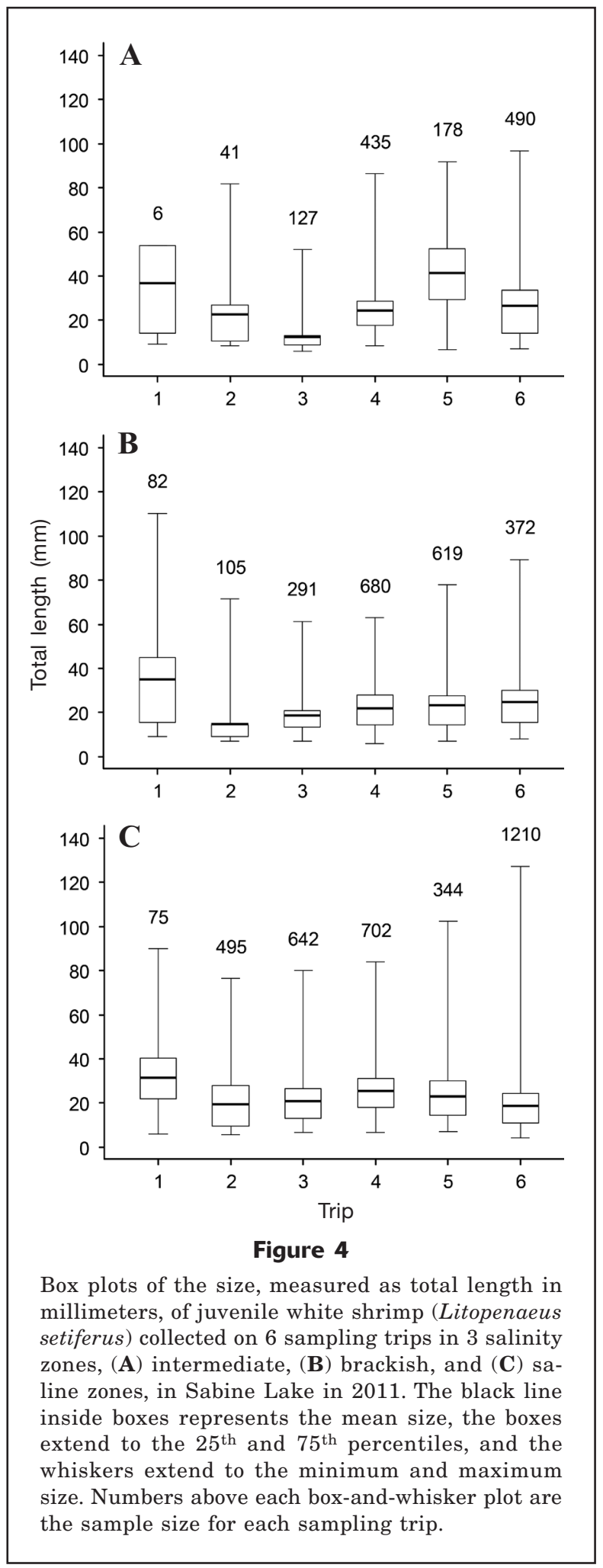

0.007] and 0.08 [SE 0.006]) and brackish (0.08 [SE 0.005 ] and 0.09 [SE 0.006]) zones, but estimates that resulted from the use of both methods showed significantly higher mortality in the brackish zone than in the intermediate zone $(0.05$ [SE 0.006] and 0.07 [SE $0.008]$ ). Only the linear-regression estimates indicated significantly greater mortality in the saline zone than in the intermediate zone.

\section{Growth}

We were unable to consistently track individual cohorts of shrimp over sampling trips in each salinity zone. Identifying individual cohorts on some sample dates was difficult because there were no clear modes that indicated separate cohorts, and the mixdist package could not adequately fit any of the 3 distributions to the data. On most sampling dates when we were able to track individual cohorts, more than 1 model had some support from AIC values; for these dates, we used model-averaged estimates for mean carapace length from models that had a combined AIC weight $\geq 0.95$ (Suppl. Tables 2 and 3).

Mean growth rate estimates among all salinity zones and cohorts combined ranged from $0.72 \mathrm{~mm}$ TL/d (SE 0.28) to $1.83 \mathrm{~mm}$ TL/d (SE 0.23) (Table 5). Among salinity zones, mean growth rates were 1.22 $\mathrm{mm} \mathrm{TL} / \mathrm{d}$ (SE 0.13), $0.99 \mathrm{~mm} \mathrm{TL} / \mathrm{d}$ (SE 0.19), and 1.62 $\mathrm{mm} \mathrm{TL/d} \mathrm{(SE} \mathrm{0.12)} \mathrm{in} \mathrm{the} \mathrm{intermediate,} \mathrm{brackish,} \mathrm{and}$ saline zones, respectively (Table 5). Mean growth rates were significantly higher in the saline zone than in the brackish and intermediate zones. No significant difference in mean growth rates was detected between the brackish and intermediate zones.

\section{Secondary production}

Secondary production of juvenile white shrimp estimated with the conservative approach (i.e., the one based on the same growth rate of $1 \mathrm{~mm} \mathrm{TL} / \mathrm{d}$ in each salinity zone) varied by salinity zone and was significantly higher in the saline than in the intermediate zone (Table 6). Secondary production in the saline zone during the 84-d sampling period was estimated as $382 \mathrm{~kg} / \mathrm{ha}$ (95\% CI, 187 to 577), which was approximately 3 times the value of $116 \mathrm{~kg} / \mathrm{ha}$ (95\% CI, 27 to 205) for the intermediate zone. In the brackish zone, production was estimated as $232 \mathrm{~kg} /$ ha (95\% CI, 102 to 361), approximately twice that of the intermediate zone. Production-to-biomass ratios over the 84-d sampling period were estimated as 5.0, 6.5 , and 7.4 in the intermediate, brackish, and saline zones, respectively (Table 6). When we used the mean growth rates estimated for each salinity zone (Table 5) to compute shrimp age and CPIs, the overall pattern of secondary production during the 84-d sampling period was the same among salinity zones, although some estimates of production were higher (intermediate $=142 \mathrm{~kg} / \mathrm{ha}$, brackish $=227 \mathrm{~kg} / \mathrm{ha}$, and saline $=614 \mathrm{~kg} / \mathrm{ha}$ ) when compared with results from the conservative approach (Table 6). Differences in production estimates appear to have been driven mainly by differences in shrimp density among salinity zones (Table 2). 
Table 2

Mean densities, measured in individuals per square meter, of juvenile white shrimp (Litopenaeus setiferus) in Sabine Lake during 6 sampling trips in 2011 in 3 salinity zones (intermediate, brackish, and saline) and 4 habitat types: 1-marsh edge, or marsh vegetation $\leq 1 \mathrm{~m}$ from the interface of marsh and open water (ME); 2-shallow water $\leq 1 \mathrm{~m}$ from the marsh edge (SW1); 3-shallow water 1-5 $\mathrm{m}$ from the marsh edge (SW1-5); and 4-shallow water $>5 \mathrm{~m}$ from the marsh edge (SW>5). A dash indicates that no sample was taken in that habitat on that date. Sample sizes for each mean range from 5 to 10 and are provided in Table 1. Standard errors (SEs) of the means are given in parentheses.

\begin{tabular}{|c|c|c|c|c|c|c|c|c|c|c|c|c|}
\hline \multirow[b]{3}{*}{ Trip } & \multicolumn{12}{|c|}{ Zone } \\
\hline & \multicolumn{4}{|c|}{ Intermediate } & \multicolumn{4}{|c|}{ Brackish } & \multicolumn{4}{|c|}{ Saline } \\
\hline & $\mathrm{ME}$ & SW1 & SW1-5 & $\mathrm{SW}>5$ & $\mathrm{ME}$ & SW1 & SW1-5 & $\mathrm{SW}>5$ & $\mathrm{ME}$ & SW1 & SW1-5 & $\mathrm{SW}>5$ \\
\hline 1 & - & $1.2(0.8)$ & $0.0(0.0)$ & $0.0(0.0)$ & - & $11.2(5.9)$ & $0.4(0.4)$ & $2.4(1.9)$ & - & $6.0(5.3)$ & $7.6(4.4)$ & $1.6(0.7)$ \\
\hline 2 & - & $7.8(4.7)$ & $0.4(0.4)$ & $0.0(0.0)$ & - & $13.6(2.7)$ & $4.6(4.1)$ & $3.0(2.0)$ & $63.0(28.2)$ & $29.4(26.2)$ & $3.8(3.1)$ & $4.0(1.5)$ \\
\hline 3 & - & $12.0(5.3)$ & $1.4(0.5)$ & $0.0(0.0)$ & - & $27.7(10.4)$ & $1.0(0.8)$ & $2.2(1.6)$ & - & $46.4(11.7)$ & $29.4(12.2)$ & $10.0(3.2)$ \\
\hline 4 & $61.8(25.4)$ & $25.2(9.4)$ & $0.4(0.4)$ & $0.2(0.2)$ & $74(22.1)$ & $58.6(23.1)$ & $2.8(1.5)$ & $1.8(0.6)$ & $60.4(24.4)$ & $65.0(36.2)$ & $6.2(3.9)$ & $10.4(3.4)$ \\
\hline 5 & $16.0(4.7)$ & $19.4(4.8)$ & $0.4(0.4)$ & $0.6(0.6)$ & $64.8(20.0)$ & $51.0(15.8)$ & $8.4(5.1)$ & $1.6(0.9)$ & $43.0(9.2)$ & $9.0(3.9)$ & $10.8(3.7)$ & $5.6(2.6)$ \\
\hline 6 & $46.8(12.6)$ & $47.8(20.7)$ & $4.0(1.3)$ & $0.6(0.2)$ & $31.4(13.4)$ & $28.8(6.6)$ & $5.8(2.1)$ & $9.4(8.4)$ & $174.0(74.6)$ & 33.0 (16.1) & $17.0(3.8)$ & $22.8(3.5)$ \\
\hline Overall mean & $41.5(10.2)$ & $17.9(4.2)$ & $1.1(0.3)$ & $0.2(0.1)$ & $56.7(11.2)$ & $31.2(5.5)$ & $3.8(1.2)$ & $3.4(1.5)$ & $85.1(22.6)$ & $33.6(7.8)$ & $12.4(2.8)$ & $9.1(1.6)$ \\
\hline
\end{tabular}

Table 3

Results of 3-way analysis of variance (ANOVA) to examine differences in mean density of juvenile white shrimp (Litopenaeus setiferus) among salinity zones, habitat types, and sampling trips in Sabine Lake in 2011. A measure of effect size, omega squared $\left(\omega^{2}\right)$, is given for each factor and can be interpreted as an estimate of the proportion of variance accounted for by each source of variation. Data used in this analysis were obtained from trips 4-6.

\begin{tabular}{lrrrrr}
\hline Factor & $\mathrm{df}$ & Sum of squares & $F$ ratio & \multicolumn{1}{c}{$P$} & $\omega^{2}$ \\
\hline Zone & 2 & 27.90 & 13.86 & $<0.0001$ & 0.06 \\
Trip & 2 & 8.80 & 4.37 & 0.0143 & 0.02 \\
Habitat type & 3 & 208.57 & 69.10 & $<0.0001$ & 0.45 \\
Zone*Trip & 4 & 13.35 & 3.32 & 0.0124 & 0.02 \\
Zone*Habitat type & 6 & 25.30 & 4.19 & 0.0006 & 0.04 \\
Trip*Habitat type & 6 & 8.92 & 1.48 & 0.1899 & 0.01 \\
Zone*Trip*Habitat type & 12 & 13.70 & 1.34 & 0.3373 & 0.00 \\
Error & 144 & 144.90 & & & \\
& & & & & \\
\hline
\end{tabular}

\section{Discussion}

The suitability of habitat for juvenile white shrimp varies among salinity zones within Sabine Lake. The saline and brackish zones provide more important nursery habitat for white shrimp than does the intermediate zone, on the basis of our estimates of shrimp density, growth, and secondary production. The intermediate zone contains the least important nursery area, although shrimp mortality rates were lower there than in the 2 other salinity zones. Although growth, mortality, and secondary production, together with density, are considered necessary for a comprehensive assessment of nursery habitat (Beck et al., 2001), and density alone may sometimes be a misleading indicator of habitat quality (Van Horne, 1983), in our study, density appeared to be an accurate indicator of habitat quality for juvenile white shrimp.

Habitat type accounted for most of the variation in density of white shrimp. Density of white shrimp was highest for habitat $\leq 1 \mathrm{~m}$ from the marsh edge and declined with increasing distance into open water in all 3 salinity zones. This general pattern for white shrimp, namely high density near the marsh edge and a decline in density in open water, has been observed in another area of Sabine Lake (Nevins et al., 2014), in Galveston Bay, Texas (Minello et al., 2008), and in Barataria Bay, Louisiana (Rozas and Minello, 2015). Densities of white shrimp at the marsh edge sites in our study area were among the highest densities reported for this species in the northern Gulf of Mexico. This concentration of shrimp may be a response to the short flooding dura- 


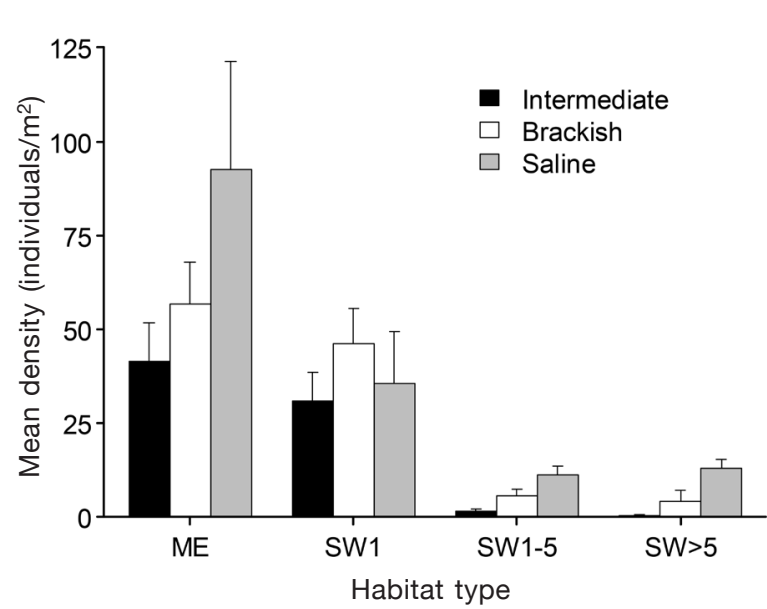

Figure 5

Comparison of mean densities of juvenile white shrimp (Litopenaeus setiferus) among 4 habitat types and 3 salinity zones (intermediate, brackish, and saline) within Sabine Lake, based on data from the last 3 sampling trips (trips 4-6) in 2011. Habitat types are 1-marsh edge ( $\mathrm{ME}$ ), or marsh vegetation $\leq 1 \mathrm{~m}$ from the interface of marsh and open water; 2 -shallow water $\leq 1 \mathrm{~m}$ from the marsh edge (SW1); 3-shallow water 1-5 m from the marsh edge (SW1-5); and 4-shallow water $>5 \mathrm{~m}$ from the marsh edge $(S W>5)$. Means and standard errors were computed from 15 replicate samples. Figure represents the significant interaction of habitat type and salinity zone.

tion of marsh $>1 \mathrm{~m}$ from the marsh edge because this short duration limited access to the vegetated marsh surface and concentrated individuals at the marsh edge sites.

Nekton density patterns in shallow water also can be influenced by the distribution of submerged aquatic vegetation (SAV) or other structure (Rozas and Minello, 2010). In our study area in 2011, SAV was absent because of an ongoing drought; however, SAV can be present, especially in the intermediate and brackish zones of estuaries during periods of normal rainfall (Chabreck, 1971). Because densities of juvenile white shrimp are similar in marsh vegetation and SAV (Howe and Wallace, 2000; Rozas and Minello, 2006), we expect that the distribution pattern of shrimp in our intermediate and brackish zones could be quite different in years of normal rainfall, when SAV beds in these locations may be extensive.

The pattern we observed in growth rates of juvenile white shrimp among salinity zones was similar to that reported for the Cape Fear River estuary in North Carolina (Laney and Copeland ${ }^{4}$ ), but the growth rates we observed in our study area were overall higher than

\footnotetext{
${ }^{4}$ Laney, R. W., and B. J. Copeland. 1981. Population dynamics of penaeid shrimp in two North Carolina tidal creeks. Rep. 81-1, 161 p. Carolina Power \& Light Co., Raleigh, NC.
}

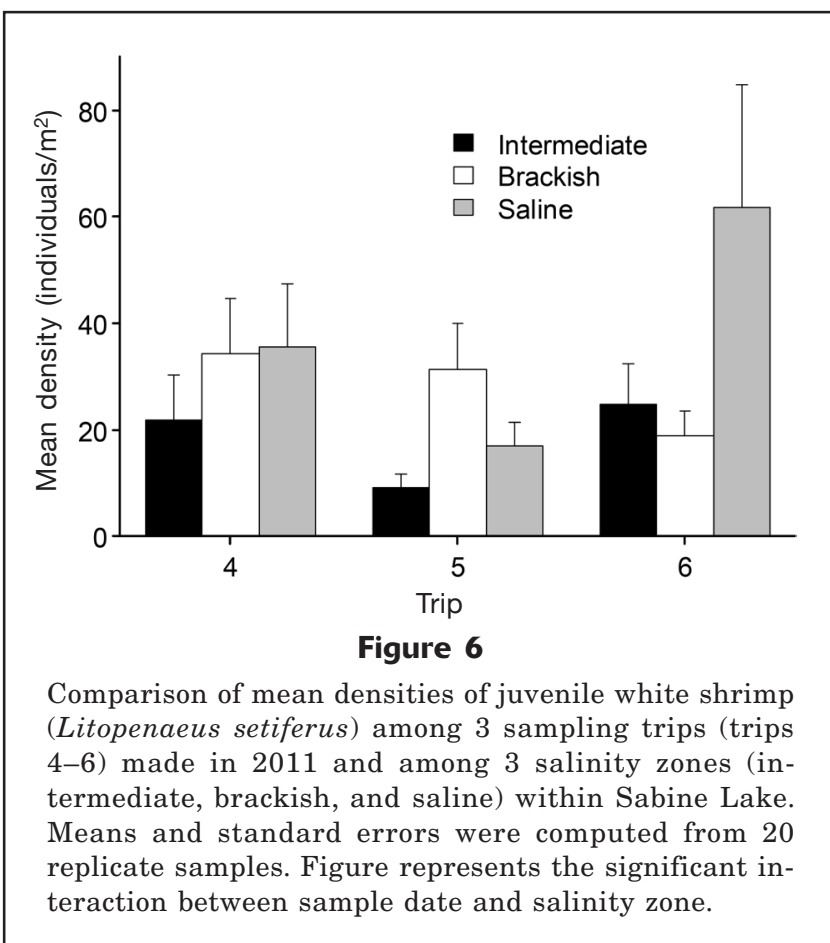

those reported in Barataria Bay (Rozas and Minello, 2011). In laboratory experiments, extremes in salinity have been shown to reduce growth rates of juvenile white shrimp (Zein-Eldin and Griffith, 1969). Salinity may directly influence growth rates through increased metabolic costs for shrimp in low-salinity (e.g., oligohaline) areas (Rozas and Minello, 2011), although this explanation did not likely pertain to our study because salinities in the intermediate zone were elevated by the ongoing drought and more typical of the brackish zone.

Although comparisons of natural mortality rates among salinity zones are rare, results of available studies indicate that mortality may increase with salinity for a variety of species. Mortality of juvenile white shrimp within marsh tidal creeks of the Cape Fear River estuary was lower in low-salinity areas than in high-salinity areas (Laney and Copeland ${ }^{4}$ ). The mortality rate for juvenile spot (Leiostomus xanthurus) in the Cape Fear estuary was lower at a low-salinity site than at a high-salinity site during the first year, although it was similar between the 2 sites in the second year (Weinstein and Walters, 1981). Mortality rates for this species and Atlantic croaker (Micropogonias undulatus) were also lower at low-salinity, up-estuary sites than at high-salinity sites near tidal inlets in both the Cape Fear River and Pamlico Sound estuaries of North Carolina (Ross, 2003). Possible explanations given by Weinstein and Walters (1981) and Ross (2003) for this pattern include the following: 1) higher density of predators at high-salinity sites, 2) higher stress on juvenile fish induced by high salinity indirectly increasing mortality, and 3) higher migration rates from saline sites biasing mortality rates upwards in those areas. 


\section{Table 4}

Daily instantaneous natural mortality estimates (and standard errors) for juvenile white shrimp (Litopenaeus setiferus) within intermediate, brackish, and saline zones of Sabine Lake. Mortality rates were estimated with 2 different catch-curve analyses, linear regression and the Chapman-Robson estimator, by using data from trips 4-6 in 2011.

\begin{tabular}{lccc}
\hline Analysis & Intermediate & Brackish & Saline \\
\hline Linear regression & $0.05(0.006)$ & $0.08(0.005)$ & $0.09(0.007)$ \\
Chapman-Robson & $0.07(0.008)$ & $0.09(0.006)$ & $0.08(0.006)$
\end{tabular}

high-salinity areas of estuaries than in the diets of predators in areas with low salinity (Minello et al., 1989) and in the diets of predators at estuarine sites near the sea than at sites farther up an estuary (Salini et al., 1990). Alternatively, this higher shrimp mortality may have been the result of less access to marsh edge habitat in the brackish and saline zones than in the intermediate zone. In the intermediate zone, marsh edge habitat was flooded for longer periods and, therefore, may have provided more protection from predators than that provided by this type of habitat in the other salinity zones.

Our secondary production estimates for juvenile white shrimp in shallow marsh habitats of Sabine Lake are similar to, and within the range of, production estimates for this species reported elsewhere. Comparisons among published values should be made cautiously, however, because of differences in definitions of the term secondary production and the methods used to estimate it. We know of no other comparisons of white shrimp production among salinity zones, but production (technically yield) of white shrimp in aquaculture ponds of different salinities was approximately 3.5 times greater in 4 ponds with high salinity ( 2 ponds at 15 and 2 ponds at 21) than in 2 low-salinity (7) ponds (Hysmith and Colura, 1976). Our estimate of $382 \mathrm{~kg} / \mathrm{ha}$ for production during the 84-d sampling period in the saline zone is higher than the estimate of annual production for juvenile white shrimp (109 kg/ha) reported for saline marshes in Galveston Bay (Minello et al., 2008; Table 4). The difference in these 2 estimates of production of juvenile white shrimp is most likely due to the higher densities we documented in our study area than those reported for Galveston Bay. Using shrimp landings data and area of emergent wetlands in the U.S. states bordering the Gulf of Mexico, Engle (2011) estimated mean annual production (technically yield) of penaeid shrimps (all species combined) as 241 $\mathrm{kg} / \mathrm{ha}$ (range: $57-1660 \mathrm{~kg} / \mathrm{ha}$ ).

The intermediate zone contained less valuable habitat than the saline zone on a per-hectare basis during the 84-d sampling period, but the estimated production from the intermediate zone, which occupies a large proportion of coastal marshes within Louisiana, was not trivial $(116 \mathrm{~kg} / \mathrm{ha})$. Therefore, the production from these low-salinity areas would contribute substantially to the total production of white shrimp in Louisiana estuaries. Multiplying our production estimates in the saline and intermediate zones by the total area of these 2 zones determined for coastal Louisiana in 2013 (Sasser et al.5), the total production over the 84-d sampling period from the intermediate zone would equal

\footnotetext{
${ }^{5}$ Sasser, C. E., J. M. Visser, E. Mouton, J. Linscombe, and S. B. Hartley. 2014. Vegetation types in coastal Louisiana in 2013: U.S. Geological Survey Scientific Investigations Map 3290, 1 sheet, scale 1:550,000. [Available at website.]
} 


\section{Table 6}

Estimates of secondary production (with 95\% confidence interval and measured as kilograms per hectare), mean biomass (measured as kilograms per hectare), and production-to-biomass ratios for juvenile white shrimp (Litopenaeus setiferus) within intermediate, brackish, and saline zones of Sabine Lake. Production (P) and biomass (B) estimates are based on data collected over an 84-d period from July through October 2011 (trips 1-6) and production was estimated by using the sizefrequency method (Garman and Waters, 1983).

\begin{tabular}{lccc}
\hline Salinity zone & Production & Biomass & P:B \\
\hline Intermediate & $115.7(26.8$ to 204.7$)$ & 23.3 & 5.0 \\
Brackish & $231.6(102.4$ to 360.8$)$ & 35.6 & 6.5 \\
Saline & $382.0(186.8$ to 577.3$)$ & 51.7 & 7.4 \\
& & & \\
\end{tabular}

44 million $\mathrm{kg}$ in comparison with 113 million $\mathrm{kg}$ from the saline zone.

Our study was conducted during drought conditions in southwest Louisiana, and the relative habitat value of the 3 salinity zones in our study area may differ during nondrought periods. During years of normal rainfall, the intermediate zone may provide less valuable habitat for white shrimp. For example, the mean density of juvenile white shrimp within the marsh edge habitat of the intermediate zone during September in 2012 , a year of normal rainfall, was $80 \%$ less than the density we observed there in the same month in 2011 and report here; whereas, shrimp densities in the same habitat type in the brackish and saline zones differed between these 2 years by $<20 \%$ (senior author, unpubl. data). Juvenile penaeid shrimp abundance and commercial landings may be higher during warm, dry periods with low freshwater inflows to estuaries (Möller et al., 2009; Piazza et al., 2010), although Gunter and Hildebrand (1954), Browder (1985), and Palmer and Montagna (2015) reported examples of a positive relationship between rainfall or freshwater inflow and the abundance or commercial landings of penaeid shrimp. More comparisons of secondary production from other estuaries conducted over several years are needed before definitive conclusions can be drawn about patterns of juvenile white shrimp production among salinity zones.

Inferences from our results are limited to the locations and time period we sampled. Our study was confined to a single year, and sampling sites were replicated in space but drawn from an area limited to 100 ha in each salinity zone. Support for extending the inferences from our study more generally, however, comes from studies of other estuaries that corroborate our results. For example, the spatial distribution and growth rates of juvenile white shrimp among salinity zones that we observed are consistent with the pattern reported from studies of Barataria Bay, Louisiana
(Rozas and Minello, 2010, 2011). In a meta-analysis of 5149 samples collected from multiple locations in the northern Gulf of Mexico, mean densities of juvenile white shrimp were highest in mesohaline and polyhaline areas (equivalent to our brackish and saline salinity zones, respectively) (Minello, 1999)—densities that were consistent with our results. Additional comparisons of demographic rates and secondary production from other estuaries of the Gulf of Mexico would allow broader inferences to be drawn in the future.

Our estimates of density, biomass, growth, natural mortality, and secondary production of juvenile white shrimp were generally higher in the saline or brackish zones and lowest in the intermediate zone. To our knowledge, this study is the first attempt to simultaneously estimate and compare population dynamics and secondary production of juvenile penaeid shrimps along an estuarine salinity gradient. Although inference from our work is limited in scope to the 3 locations and the time period we sampled, the saline and brackish zones provided more important nursery habitat for juvenile white shrimp than such habitat in the intermediate zone. The total amount of production from the intermediate zone, however, was not trivial when the area that this zone covers in coastal Louisiana is considered. Nursery habitats that provide a small contribution on a per-area basis, such as the intermediate zone in our study area, may still have a large effect at the population level because the habitat covers a relatively large total area (Dahlgren et al., 2006). Moreover, the relative value of nursery habitats can be dynamic, with variation occurring both spatially (e.g., within as well as among estuaries) and temporally, from year to year (Kraus and Secor, 2005). We documented withinestuary (i.e., among salinity zones) differences in habitat value for white shrimp in Sabine Lake and expect this value, especially in the intermediate zone, to vary interannually. For example, the habitat value of the intermediate zone in our study area likely would be less in a year in which rainfall was greater than or equal to average levels (i.e., in a year of lower salinity) than in the year we documented, 2011, a year of severe drought and relatively high salinity. This dynamic nature of habitat value should be considered when assessing estuarine nursery areas.

\section{Acknowledgments}

We thank S. Hillen and J. Salas of the NOAA Southeast Fisheries Science Center's (SEFSC) Galveston Laboratory; L. Broussard, S. Beck, and D. O'Malley of Louisiana State University; A. Cummings of the SEFSC Estuarine Habitats and Coastal Fisheries Center in Lafayette, Louisiana; and J. C. Robichaux and J. Thompson of the University of Louisiana at Lafayette for help collecting and processing samples. We would also like to thank D. Richard at Stream Wetland Services, Lake Charles, Louisiana, for helping to locate sites and for providing lodging, the staff at Murphree 
Wildlife Management Area for providing lodging, and the staff of the Texas Point National Wildlife Refuge for access to one of our field sites. We thank P. Caldwell for conducting the GIS analysis needed to weight the length-frequency distributions and for creating Figure 1. A teaching assistantship from the University of Louisiana at Lafayette, the Rockefeller Wildlife Scholarship, the Coastal Conservation Association/Ted Beaulieu Sr. Scholarship, a research grant from the Wetland Foundation, and the SEFSC provided funding for this project. We also thank T. Minello and 3 anonymous reviewers whose comments improved this article.

\section{Literature cited}

Anonymous.

1958. Symposium on the classification of brackish waters. Oikos 9:311-312. Article

Baker, R., and T. J. Minello.

2010. Growth and mortality of juvenile white shrimp Litopenaeus setiferus in a marsh pond. Mar. Ecol. Prog. Ser. 413:95-104. Article

Baker, R., M. Fujiwara, and T. J. Minello.

2014. Juvenile growth and mortality effects on white shrimp Litopenaeus setiferus population dynamics in the northern Gulf of Mexico. Fish. Res. 155:74-82. Article

Baxter, K. N., and W. C. Renfro.

1967. Seasonal occurrence and size distribution of postlarval brown and white shrimp near Galveston, Texas, with notes on species identification. Fish. Bull. 66:149-158.

Beck, M. W., K. L. Heck Jr., K. W. Able, D. L. Childers, D. B. Eggleston, B. M. Gillanders, B. Halpern, C. G. Hays, K. Hoshino, T. J. Minello, et al.

2001. The identification, conservation, and management of estuarine and marine nurseries for fish and invertebrates. BioScience. 51:633-641. Article

Benke, A. C.

1979. A modification of the Hynes method for estimating secondary production with particular significance for multivoltine populations. Limnol. Oceanogr. 24:168171. Article

Boesch, D. F., and R. E. Turner.

1984. Dependence of fishery species on salt marshes: the role of food and refuge. Estuaries 7:460-468. Article

Browder, J. A.

1985. Relationship between pink shrimp production on the Tortugas Grounds and water flow patterns in the Florida Everglades. Bull. Mar. Sci. 37:839-856.

Burnham, K. P., and D. R. Anderson.

2002. Model selection and multimodel inference: a practical information-theoretic approach, $2^{\text {nd }}$ ed., 488 p. Springer, New York.

Chabreck, R. H.

1970. Marsh zones and vegetation types in the Louisiana coastal marshes. Ph.D. diss., 113 p. Louisiana State Univ., Baton Rouge, LA.

1971. Ponds and lakes of the Louisiana coastal marshes and their value to fish and wildlife. Proc. Annu. Conf. SEAFWA 25:206-215.

Chapman, D. G., and D. S. Robson.

1960. The analysis of a catch curve. Biometrics 16:354-368. Article
Dahlgren, C. P., G. T. Kellison, A. J. Adams, B. M. Gillanders, M. S. Kendall, C. A. Layman, J. A. Ley, I. Nagelkerken, and J. E. Serafy.

2006. Marine nurseries and effective juvenile habitats: concepts and applications. Mar. Ecol. Prog. Ser. 312:291-295. Article

Dall, W., B. J. Hill, P. C. Rothlisberg, and D. J. Sharples. 1990. The biology of the Penaeidae. Adv. Mar. Biol. 27:1-484.

Diop, H., W. R. Keithly Jr., R. F. Kazmierczak Jr., and R. F. Shaw.

2007. Predicting the abundance of white shrimp (Litopenaeus setiferus) from environmental parameters and previous life stages. Fish. Res. 86:31-41. Article

Ditty, J. G.

2011. Young of Litopenaeus setiferus, Farfantepenaeus aztecus and $F$. duorarum (Decapoda: Penaeidae): A reassessment of characters for species discrimination and their variability. J. Crustac. Biol. 31:458-467. Article

Dolbeth, M., M. Cusson, R. Sousa, and M. A. Pardal.

2012. Secondary production as a tool for better understanding of aquatic ecosystems. Can. J. Fish. Aquat. Sci. 69:1230-1253. Article

Engle, V. D.

2011. Estimating the provision of ecosystem services by Gulf of Mexico coastal wetlands. Wetlands. 31:179-193. Article

Garman, G. C., and T. F. Waters.

1983. Use of the size-frequency (Hynes) method to estimate annual production of a stream fish population. Can. J. Fish. Aquat. Sci. 40:2030-2034. Article

Gunter, G., and H. H. Hildebrand.

1954. The relation of total rainfall of the state and catch of the marine shrimp (Penaeus setiferus) in Texas waters. Bull. Mar. Sci. 4:95-103.

Gunter, G., J. Y. Christmas, and R. Killebrew.

1964. Some relations of salinity to population distributions of motile estuarine organisms, with special reference to penaeid shrimp. Ecology (USA) 45:181-185. Article

Heck, K. L., Jr., G. Hays, and R. J. Orth.

2003. Critical evaluation of the nursery role hypothesis for seagrass meadows. Mar. Ecol. Prog. Ser. 253:123-136. Article

Howe, J. C., and R. K. Wallace.

2000. Relative abundance of postlarval and juvenile penaeid shrimps in submerged aquatic vegetation and emergent marsh habitats. Gulf Mex. Sci. 18:130-137.

Howe, J. C., R. K. Wallace, and F. Scott Rikard.

1999. Habitat utilization by postlarval and juvenile penaeid shrimps in Mobile Bay, Alabama. Estuaries 22:971979. Article

Hysmith, B. T., and R. L. Colura.

1976. Effect of salinity on growth and survival of penaeid shrimp in ponds. J. World Aquat. Soc. 7:289-303. Article

Kathiresan, K., and B. L. Bingham.

2001. Biology of mangroves and mangrove ecosystems. Adv. Mar. Biol. 40:81-251. Article

Kneib, R. T.

1997. The role of tidal marshes in the ecology of estuarine nekton. Oceanogr. Mar. Biol. Annu. Rev. 35:163-220.

2003. Bioenergetic and landscape considerations for scaling expectations of nekton production from intertidal marshes. Mar. Ecol. Prog. Ser. 264:279-296. Article 
Kraus, R. T., and D. H. Secor.

2005. Application of the nursery-role hypothesis to an estuarine fish. Mar. Ecol. Prog. Ser. 291:301-305. Article

Macdonald, P., and J. Du.

2012. Mixdist: finite mixture distribution models. $\mathrm{R}$ package vers. 0.5-4. [Available at website, accessed October 2015.]

Mace, M., III, and L. P. Rozas.

2015. Estimating natural mortality rates of juvenile white shrimp Litopenaeus setiferus. Estuar. Coasts 38:15801592. Article

Milliken, G. A., and D. E. Johnson.

1992. Analysis of messy data. Vol. 1: designed experiments, 473 p. Chapman and Hall, London.

Minello, T. J.

1999. Nekton densities in shallow estuarine habitats of Texas and Louisiana and the identification of essential fish habitat. Am. Fish. Soc. Symp. 22:43-75.

Minello, T. J., R. J. Zimmerman, and T. E. Czapla.

1989. Habitat-related differences in diets of small fishes in Lavaca Bay, Texas, 1985-1986. NOAA Tech. Memo. SEFC-NMFS-236, $16 \mathrm{p}$

Minello, T. J., K. W. Able, M. P. Weinstein, and C. G. Hays.

2003. Salt marshes as nurseries for nekton: testing hypotheses on density, growth and survival through metaanalysis. Mar. Ecol. Prog. Ser. 246:39-59. Article

Minello, T. J., G. A. Matthews, P. A. Caldwell, and L. P. Rozas. 2008. Population and production estimates for decapod crustaceans in wetlands of Galveston Bay, Texas. Trans. Am. Fish. Soc. 137:129-146. Article

Minello, T. J., L. P. Rozas, and R. Baker.

2012. Geographic variability in salt marsh flooding patterns may affect nursery value for fishery species. Estuar. Coasts 35:501-514. Article

Möller, O. O., Jr., J. P. Castello, and A. C. Vaz.

2009. The effect of river discharge and winds on the interannual variability of the pink shrimp Farfantepenaeus paulensis production in Patos Lagoon. Estuar. Coasts 32:787-796. Article

Muncy, R. J.

1984. Species profiles: life histories and environmental requirements of coastal fishes and invertebrates (Gulf of Mexico)—white shrimp. U.S. Fish Wildl. Serv. FWS/ OBS-82/11.20. U.S. Army Corps Eng., TR EL-82-4, 19 p.

Nance, J. M., C. W. Caillouet Jr., and R. A. Hart.

2010. Size-composition of annual landings in the white shrimp, Litopenaeus setiferus, fishery of the northern Gulf of Mexico, 1960-2006: its trend and relationships with other fishery-dependent variables. Mar. Fish. Rev. 72:1-13.

Nevins, J. A., J. B. Pollack, and G. W. Stunz.

2014. Characterizing nekton use of the largest unfished oyster reef in the United States compared with adjacent estuarine habitats. J. Shellfish Res. 33:227-238. Article

NMFS (National Marine Fisheries Service).

2010. Marine fisheries habitat assessment improvement plan. Report of the National Marine Fisheries Service Habitat Assessment Improvement Plan Team. NOAA Tech. Memo. NMFS-F/SPO-108, 115 p.

Olejnik, S., and J. Algina.

2003. Generalized eta and omega squared statistics: measures of effect size for some common research designs. Psychol. Methods 8:434-447. Article
Palmer, T. A., and P. A. Montagna.

2015. Impacts of droughts and low flows on estuarine water quality and benthic fauna. Hydrobiologia 753:111-129. Article

Piazza, B. P., M. K. La Peyre, and B. D. Keim.

2010. Relating large-scale climate variability to local species abundance: ENSO forcing and shrimp in Breton Sound, Louisiana, USA. Clim. Res. 42:195-207. Article

Pullen, E. J., and W. L. Trent.

1969. White shrimp emigration in relation to size, sex, temperature and salinity. FAO Fish. Rep. 57:1001-1014.

$\mathrm{R}$ Core Team.

2014. R: a language and environment for statistical computing. R Foundation for Statistical Computing, Vienna, Austria. [Available from website, accessed April 2014]

Rakocinski, C. F., D. M. Baltz, and J. W. Fleeger.

1992. Correspondence between environmental gradients and the community structure of marsh-edge fishes in a Louisiana estuary. Mar. Ecol. Prog. Ser. 80:135-148.

Ricker, W. E.

1975. Computation and interpretation of biological statistics of fish populations. Bull. Fish. Res. Board Can. $191,382 \mathrm{p}$.

Rose, K. A., H. Huang, D. Justic, and K. de Mutsert.

2014. Simulating fish movement responses to and potential salinity stress from large-scale river diversions. Mar. Coast. Fish. 6:43-61. Article

Ross, S. W.

2003. The relative value of different estuarine nursery areas in North Carolina for transient juvenile marine fishes. Fish. Bull. 101:384-404.

Rozas, L. P., and T. J. Minello.

2006. Nekton use of Vallisneria americana Michx. (Wild celery) beds and adjacent habitats in coastal Louisiana. Estuar. Coasts 29:297-310. Article

2010. Nekton density patterns in tidal ponds and adjacent wetlands related to pond size and salinity. Estuar. Coasts 33:652-667. Article

2011. Variation in penaeid shrimp growth rates along an estuarine salinity gradient: implications for managing river diversions. J. Exp. Mar. Biol. Ecol. 397:196-207. Article

2015. Small-scale nekton density and growth patterns across a saltmarsh landscape in Barataria Bay, Louisiana. Estuar. Coasts 38:2000-2018. Article

Rozas, L. P., T. J. Minello, and D. D. Dantin.

2012. Use of shallow lagoon habitats by nekton of the northeastern Gulf of Mexico. Estuar. Coasts 35:572586. Article

Salini, J. P., S. J. M. Blaber, and D. T. Brewer.

1990. Diets of piscivorous fishes in a tropical Australian estuary, with special reference to predation on penaeid prawns. Mar. Biol. 105:363-374. Article

Schenker, N., and J. F. Gentleman.

2001. On judging the significance of differences by examining the overlap between confidence intervals. Am. Stat. 55:182-186. Article

Smith, M. W., A. Y. Then, C. Wor, G. Ralph, K. H. Pollock, and J. M. Hoenig.

2012. Recommendations for catch-curve analysis. North Am. J. Fish. Manage. 32:956-967. Article

Turner, R. E.

1990. Landscape development and coastal wetland losses in the northern Gulf of Mexico. Am. Zool. 30:89-105. Article 
Van Horne, B.

1983. Density as a misleading indicator of habitat quality. J. Wildl. Manage. 47:893-901. Article

Vance, D. J., M. D. E. Haywood, D. S. Heales, R. A. Kenyon, and N. R. Loneragan.

1998. Seasonal and annual variation in abundance of postlarval and juvenile banana prawns Penaeus merguiensis and environmental variation in two estuaries in tropical northeastern Australia: a six year study. Mar. Ecol. Prog. Ser. 163:21-36. Article

Vetter, E. F.

1988. Estimation of natural mortality in fish stocks: a review. Fish. Bull. 86:25-43.

Visser, J. M., C. E. Sasser, R. H. Chabreck, and R. G. Linscombe. 1998. Marsh vegetation types of the Mississippi River Deltaic Plain. Estuaries 21:818-828. Article

Visser, J. M., C. E. Sasser, R. H. Chabreck, and R. G. Linscombe. 2000. Marsh vegetation types of the Chenier Plain, Louisiana, USA. Estuaries. 23:318-327. Article

Wagner, C. M., and H. M. Austin.

1999. Correspondence between environmental gradients and summer littoral fish assemblages in low salinity reaches of the Chesapeake Bay, USA. Mar. Ecol. Prog. Ser. 177:197-212. Article
Weinstein, M. P., and M. P. Walters.

1981. Growth, survival and production in young-of-year populations of Leiostomus xanthurus Lacépéde residing in tidal creeks. Estuaries 4:185-197. Article

Weinstein, M. P., S. L. Weiss, and M. F. Walters.

1980. Multiple determinants of community structure in shallow marsh habitats, Cape Fear River estuary, North Carolina, USA. Mar. Biol. 58:227-243. Article

Zein-Eldin, Z. P., and G. W. Griffith.

1969. An appraisal of the effects of salinity and temperature on growth and survival of postlarval penaeids. FAO Fish. Rep. 57:1015-1026.

Zimmerman, R. J., T. J. Minello, and G. Zamora Jr.

1984. Selection of vegetated habitat by brown shrimp, Penaeus aztecus, in a Galveston Bay salt marsh. Fish. Bull. 82:325-336.

Zimmerman, R. J., T. J. Minello, and L. P. Rozas.

2000. Salt marsh linkages to productivity of penaeid shrimps and blue crabs in the northern Gulf of Mexico. In Concepts and controversies in tidal marsh ecology (M. P. Weinstein and D. A. Kreeger, eds.), p. 293-314. Kluwer Academic Publishers, Dordrecht, Netherlands. 